\title{
ACTION DIRECTIONS REGARDING THE DEVELOPMENT OF YOUTH TRAVEL IN ROMANIA
}

\author{
Claudia Olimpia Moisă $\breve{l}^{1}$
}

ABSTRACT: The mutations that are currently manifesting in the global economy are influencing in a positive manner the development of youth travel, and the main quantitative and qualitative directions that are being shaped internationally and in Europe are also leaving a mark on the evolution tourism for young people in our country.

By analyzing the framework favourable for the development of youth travel in our country, we have prepared a series of courses of action for its development, courses that have been structured on several levels: the development and diversification of the tourism supply, the broader promotion of a system of facilities, marketing actions, the improvement of the legal and institutional frameworks, etc.

Key words: youth travel, youth travel in Romania, development of youth travel.

JEL codes: $L 83$

\section{Introduction}

Romania has a rich and varied potential that allows the development of tourism in general, but it also has a variety of forms of tourism, including youth travel. However, tourism has a modest contribution to economic development, which proves that the high tourism potential is not exploited properly. Without a doubt, one of the ways to adequately capitalize on the tourism resources of Romania is youth travel due to the diverse motivations of young people to travel to new and interesting destinations. The emergence of Romania as a new destination for European and international youth travel could have extremely beneficial effects for the national economy. Tourism can create an image for our country that may be beneficial or not and influences the international tourists arrival flows or the investments. Thus, a new destination stirs up the interest of foreign tourists to explore new regions and the increased volume of tourists means increased capital.

The purpose of this paper is to outline the main lines of action to develop youth tourism in Romania. Its contribution to tourism research in Romania youth contributions materialize both theoretical and practical results of research and analysis undertaken and can be summarized as follows:

- Prospects of development of Romanian youth tourism in the broader context of its development at European and international level

- Identify the main lines of action in Romanian youth tourism

- Grouping of these lines into four main categories

- Detailed analysis of the four categories of guidelines for youth tourism in Romania and their concrete examples.

\section{Literature review}

Tourism practiced by young people as an area of interest to researchers stated, more conspicuously, only after 1991, when the Conference of the World Tourism Organization (WTO,

\footnotetext{
1 “1 Decembrie 1918” University of Alba Iulia, Romania, email: claudiapatrut@yahoo.com
} 
1991) in New Delhi main subject was the young travelers. Subsequent studies have shown that youth tourism is an important component (Jones, 2007) (Travel \& Tourism Analyst, 2004, 2009), rising (Regroupement Tourisme Jeunesse, 2001; BITS, 2001) with the international tourism market a significant contribution to economic and socio-cultural and youth (Richards and Wilson, 2003, 2008, Gonzalez Ortega, 2002; Istrate and Glăvan, 1994), in particular.

Earlier studies of youth tourism partially covers the vast and complex issue of this form of tourism, focusing primarily on international and regional approaches. As for Romania, there is a lack of specialist training in youth tourism, except for some studies that touch tangentially issue this form of tourism. It's about research undertaken by certain Romanian organizations (ANSIT, 2007, 2008, ANT - 2006) for the Ministry of Regional Development and Tourism and Sports and Youth Authority or for its own needs (Youth Hostel Association of Romania, the Association of Euro <26 Romania) or international (World Travel \& Tourism Council - WTTC - 2009, World Tourism Organization, the European Parliament).

From the results of researches dealing (Moisă, 2011) with the youth tourism in Romania can conclude that this form of tourism is a booming part of the tourist market with outstanding growth prospects due to the competitive advantages that our country has as a destination for youth travel, namely:

- It has an advantageous geographical location and easy access from the EU;

- It has natural areas suitable for adventure tourism;

- It is a cheap destination;

- It provides a favourable, hospitable environment, etc.

In this context, represented on the one hand, the limits of the reference studies, on the other hand, the prospects of young Romanian tourism, this paper aims to address more detailed aspects of the main directions of action for its development .

\section{Research methodology}

Based on previous personal research (Moisă, 2011) on youth tourism in Romania, in this paper I identified and analyzed the main lines of action in the development of this form of tourism in our country. In order to outline directions for action on youth Romanian tourism development have revealed first major changes currently taking place in the world economy and international perspectives in Europe.

To achieve its objectives, I designed the next logical research:

- Theoretical research, by studying the specialized international literature references, using specific techniques as analysis, synthesis, exposure argued comparative analysis of various policies adopted by countries of the world in youth tourism, prospective analysis of its development prospects.

- Documentation practice, achieved through research and a detailed analysis of the tourism market in Romania

- You capture mutations taking place currently in the global economy and quantitative or qualitative objectives who put their mark on youth tourism

- The formulation of the main lines of action on youth tourism development in our country

\section{Courses of action for the development of youth travel in Romania}

Among the major phenomena in global economy that leave a mark on tourism, the most important are:

- globalisation

- $\quad$ sustainable development

- the development of the tertiary sector (services), particularly informatics

These structural changes taking place worldwide influence people's travels in general and young people's in particular. If the financial and economic crisis has negatively influenced youth 
travel in recent years, demography, globalisation, the growing importance of the tertiary sector, sustainable development, computerization or the new direction - "knowledge society" - have a positive impact, leading to its development.

In the context of the mutations that are currently occurring in global economy and which represent a benchmark for the evolution of youth travel, certain guidelines are being shaped at international and European level that have direct consequences over the prospects and courses of action for its development in Romania as well.

Starting from the mentioned aspects and in conjunction with the developments in global economy, a few major guidelines can be outlined in the dynamic of youth travel:

- Firstly, quantitative - an increase in the interest for the development of youth travel through wider involvement from stakeholders, increasing the number of tourists, specialized bodies, programs and facilities;

- Secondly, qualitative, structural mutations - diversification of tourism products for youth (adventure, educational, cultural, sports, etc.), emergence of new tourist destinations, quality service improvement as a result of increased demands from young tourists, development and diversification of the provided range of benefits, creating new partnerships, etc.

In line with the developments in Europe and the developments of Romanian economy and tourism as a whole, and in line with the prospects of youth travel defined on the bases of forecasts, it's necessary to take measures and to impose actions that stimulate the development of this type of tourism and that, on one hand, encourage youth to travel more and, on the other hand, encourage tour operators to promote programs specific for young people (see fig. no 1).

These measures, in line with broader objectives of a strategy in the field, can be structured on several levels: the development and diversification of the tourism supply, the broader promotion of a system of facilities, marketing actions, the improvement of the legal and institutional frameworks, etc.

1. In terms of the tourism supply, the main directions of modernization, development and diversification refer to:

Specific infrastructure, in particular the development of networks of youth hostels and hotels. The idea that young people prefer leisure tourism could also be taken into account in Romania and, like other countries with tradition (for example, France), Romania could develop a network of holiday centres that are considered as complementary areas to family and school, where children and young people are accommodated during holidays and where teams of qualified animators work, whose mission is to contribute to the integration, education and development of children during school breaks. We also propose the set up of Youth Travel Centers, co-financed by the Ministry of Regional Development and Tourism in partnership with other governmental or non-governmental bodies or economic agents, where young people can spend their vacation and the expenses are largely subsidized by sponsors or families. The wide range of natural values and the poor infrastructure in certain areas of the country represent a favourable environment for the development of active and adventure travel. Identifying and developing trails for hiking, cycling, canoeing and rafting routes, areas for diving and other specific features is an activity that doesn't require significant financial investments, which can be made on short-term and are economically sustainable on long-term. In recent years, off-road has gain momentum in Romania and currently there is one approved road at Izvoranu in Buzau county (see fig. no.2). 


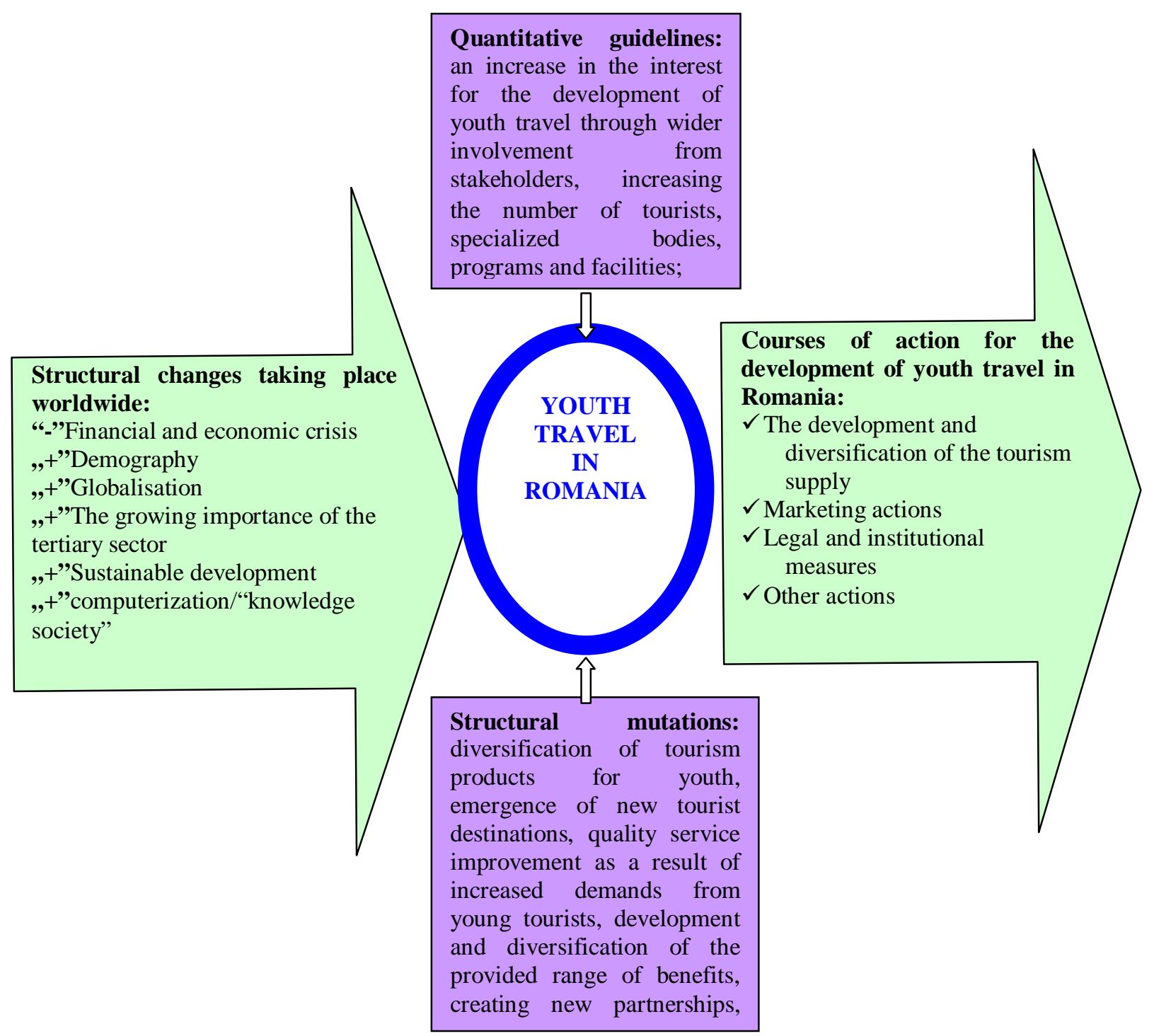

Fig. no. 1 - Incentives for the Romanian youth tourism

To develop sports and adventure travel, someone has to develop and approve as many roads of this type because otherwise these activities will take place in a chaotic manner that will destroy the environment.

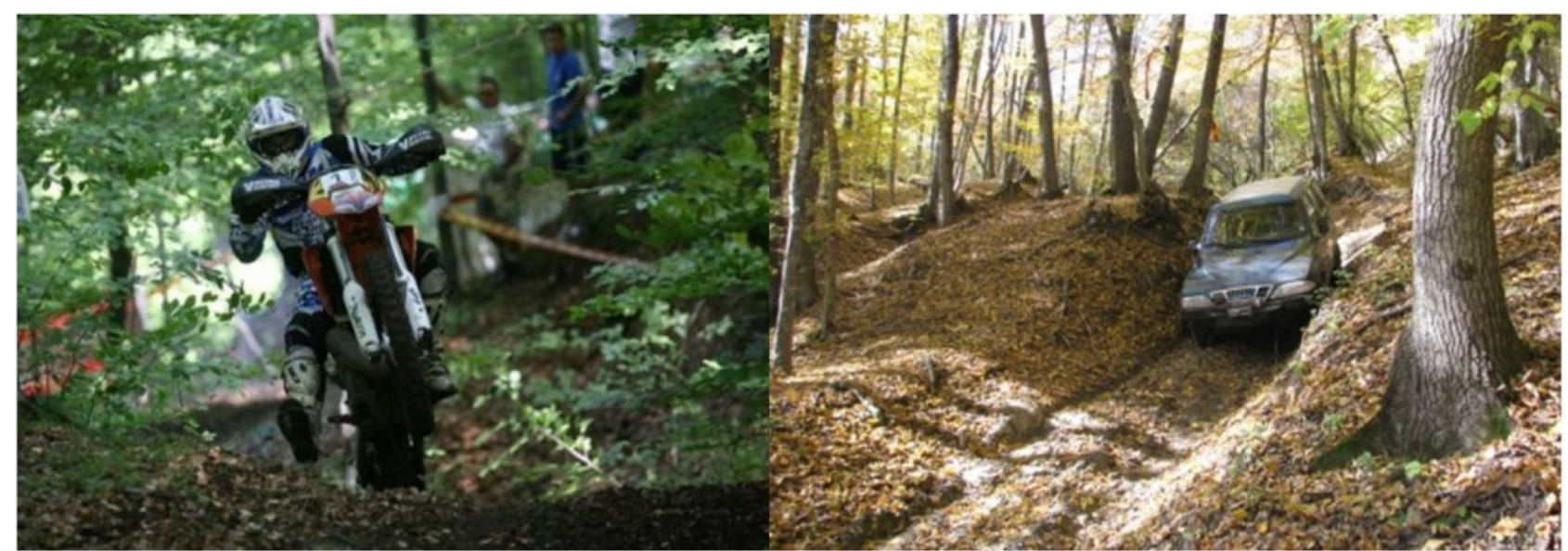

Figure no. 2 - Off-road Circuite Izvoranu (Buzău county) 
Theme parks ca also be developed - set up at the periphery of the most important urban centers and resorts (for example, Bucharest, Cluj Napoca, Timişoara, Iaşi, Costinești, Predeal etc.) or in areas that provide favourable conditions for the development of adventure travel (the Meridionali Carpathians, the Apuseni Mountains, etc.) and that provide various recreationentertainment facilities. The examples could include water parks (such as Aqua Magic in Mamaia resort - see fig. no 3), amusement parks, adventure or cultural parks (the latter being an attraction for external markets also). Currently, in Romania there are two adventure parks: the biggest is in Braşov (see fig. no 4) and the second park is located in Harghita Băi;

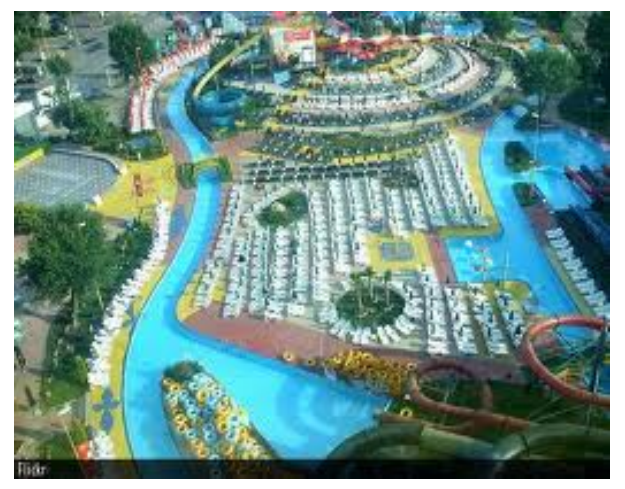

Fig. no 3 - Aqua Magic park Mamaia

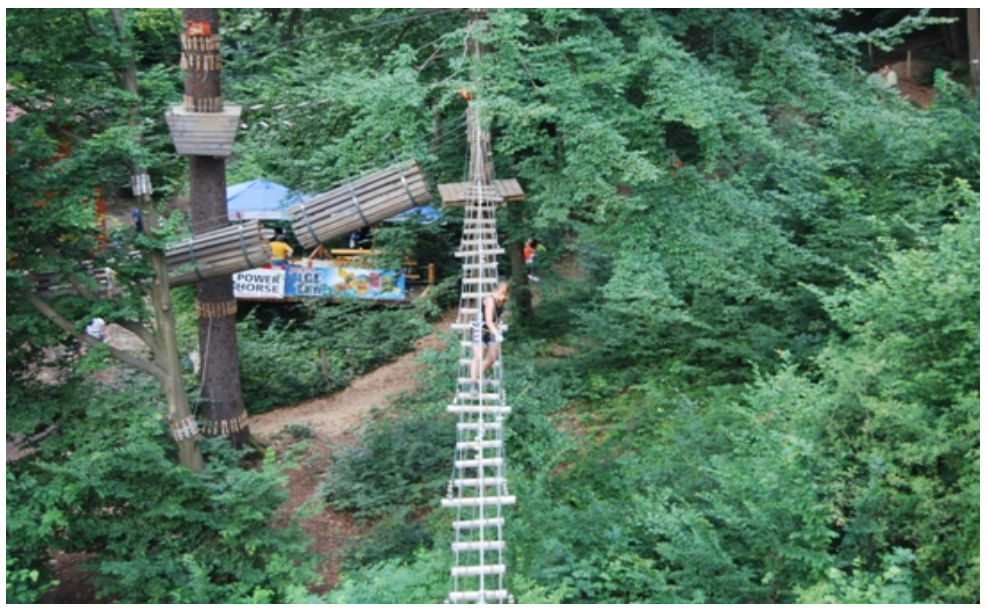

Fig. no 4 - Aventura Park Braşov

$>\quad$ The specialization of trip organizers on this segment of customers and on certain tourism products/programs, such as: cultural tours like "On the footsteps of ... Dacians, dwarf dinosaurs, Mihai Viteazu" or initiating cross-cultural projects that can lead to a better interpersonal knowledge between the young participants in cultural exchange programs that take place between Romania and other countries. Based on the objectives of the European Union regarding the European Year of Volunteering (2011), Romania can implement a series of specific actions: adopting and implementing policies to stimulate volunteerism; developing local and regional partnerships to promote volunteer activities; increasing the involvement of citizens in this type of activity. In order to promote youth travel on the domestic and international markets, we must emphasize the development and diversification of tourism products aimed at young tourists by providing other tourism services than those considered basic (meals and accommodation), particularly recreation and entertainment services. Thus, tourist activities can have an educational purpose, approaching intercultural issues, issues about: the identity of national culture, tourism and 
environmental behaviour, moral and religious aspects, landscape aesthetics, scientific issues, acquiring technical skills, etc. Because not all young Romanians can afford to practice some form of youth travel, such as going to theme parks, destinations or tourist locations can develop vacation clubs where activities aimed at youth can take place in workshops where specialized animators participate. Examples of such workshops are: communicating and play in English, French, German, Spanish, etc., hardware and modelling (making objects, jewels, cardboards and natural materials, etc.); music and dance (music and dance activities, gymnastics, outdoors sports) etc.;

Providing discounts and facilities. It's about the wide-scale expansion of youth card systems and of the associated range of facilities and the discounts and rates offered to young people directly by the organizers and providers of tourist services. A youth holiday vouchers system could be implemented at national level, which will be financed from a fund created through the contribution of interested economic agents and institutions or the contribution of various individuals. Even if there are many discounts and facilities provides by these cards in our country, young people are not sufficiently informed about their existence.

$>$ Improving the quality of tourism services. One of the most important constraints for the short-term development of this form of tourism in our country is the poor quality of tourism services, particularly in school camps, which are managed by the National Authority for Sports and Youth within the Ministry of Regional Development and Tourism. In order to be able to face the market competition, one must promote certain quality standards for tourism facilities and endowments, which must be in line with the European quality standards in the hospitality industry. We are talking about developing quality standards for tourism services provided in accommodation units for youth and requiring from providers, through specific regulations, to comply with these standards, as well as to use the classification standards of accommodation units as a tool to improve service quality. These standards should refer to: security and protection of youth, hygiene, accessibility, transparency, authenticity and harmony with the human and natural environment. Using incentives, such as giving awards and showing the appreciation of specialized institutions and organizations, is beneficial in raising the standards of youth travel.

2. The marketing actions refer to:

$>$ Improving tourist information services by:

- Creating a network of tourist information centers. Romania has a rich tourism heritage, but these attractions are not fully promoted to young people. Internationally speaking, there is a series of similar tourism resources that generate additional revenues due to the promotion through tourist information centers. Consequently, such a network should be developed at national level, which will ensure the process of providing information about tourism and more to young people. These centers will be located in academic centers and at the destinations preferred by youth (Costineşti, Predeal, etc).

- Creating a tourist information website for young people. In Romania there are several tourist information websites, the most recent being www.skytrip.ro, launched on March $1^{\text {st }} 2011$, but which isn't exclusively aimed at young people. In this regard, we recommend creating a tourist information website for youth where to find comprehensive information, updated daily, about all the tourist objectives in our country, hostels, school camps, dorms and dining facilities in all the locations, details about modes of transport and tourist routes, as well as information about the main recreation locations. In Europe, this can be done with the help of the Portal for European tourist destinations created with the financial support of the European Commission;

- Supporting the publishing of documentation and promotional materials specific for the interests of young people in collaboration with bodies and specialized publishing houses. In this regard, we recommend developing a tourist guide by the Ministry of Regional Development and Tourism in collaboration with economic agents, the National Authority for Consumer Protection, as well as national tourism associations in our country. The guide will promote the rights of young tourists and will include information about their prerogatives regarding the services 
of accommodation, dining and recreation based on contracts with the suppliers of such services. The guide will also include information about the classification systems (exemplified by icons), the privileges of young people as consumers of transport services, such as air, rail, road and water travel, and implicitly about the provided facilities and discounts, information about the rights and obligations of youth as clients of travel agencies, about insurance policies, medical assistance, visas, the protection of tourist rights and the contact data of specialized bodies and associations, the existing rules concerning the protection of national heritage resources, as well as information about the local tourist taxes or any other information with direct implications on youth travel.

$>$ Attracting new segments of tourist segments both inside and outside the country, such as students, young families with or without children or disadvantaged youth that generally are not members of youth associations, clubs or non-governmental organizations. The development of the tourist market from this perspective can be done primarily by providing facilities from producers and providers of tourism products and services or by coordinating the activities of other bodies and governmental agencies with impact on the development of youth travel and, implicitly, by adapting promotional strategies to the specific of this market;

Better promotion of Romania as a destination for young people both on the domestic market and on the international market, because Romania has a considerable potential that is more suitable to practicing certain forms of youth travel than other European and global destinations through the following activities:

- Promoting the tourism supply among Romanian and foreign youth. A particularly important role in developing Romanian youth travel is played by promoting the tourism supply among Romanian and foreign youth. Although many countries are actively involved in the promotional activity, in Romania, such a marketing task tends to be limited only to general tourism fairs where very few youth travel operators participate and to a few tourism fairs for students and young people and to providing discounts for transport and/or for tourist attractions and services. However, over time, there have been shy attempts to organize youth and student tourism fairs, such as: the Fair of Travel Agencies - youth offers (1999-2001), the National Fair for Youth Travel TNT Junior (2000-2001), the Days of School Tourism (2001-2005) and the Turistud National Tourism Fair (2003-2007). The in-depth knowledge of Romania as a youth tourist destination and of its supply of tourist services is weak among the tour operators and the personnel working in tourism agencies on the main markets, and these employees can't "sell" a destination they know little about at best. Romania's comprehensive program at tourism fairs from abroad should also include the promotion of Romanian youth travel as there is insufficient exposure of our country and its products for young tourists, leading to an unclear perception of the country as a serious and original destination;

- Developing and implementing a youth marketing strategy. Currently, Romania doesn't have a marketing strategy for tourism and there is a lack of coordination between the promotional efforts of the Ministry of Regional Development and Tourism, of tourism associations and institutions, of local authorities and private operators. This lead to the fragmentation of the presentation of the tourism products of our country and it represented a very important factor that contributed to the lack of sufficient tourism products to attract significant tourist arrivals. Creating a strategy for the development of youth travel should be related to wide range of specific tourism products and it can be better implemented by creating a network of tourist information centers and by organizing exhibitions. Both the state institutions and the non-governmental institutions have to develop youth marketing strategies tailored for: adventure travel and exploring new destinations, the more direct contact with the environment, offering more varied trips and shorter stays, increasing the interest for last-minute products and low-costs offers, developing new cultural horizons (gastronomy, traditions, folklore, crafts), promoting certain types of tourism products national and European sports and music events, etc.;

- Setting up a group of experts to develop a marketing campaign aimed at young people 
aged 15 to 25 . This campaign should consist in creating websites dedicated to young tourists (such an example could be www.youngtouristinromania.ro) and Romanian experts providing permanent advice. The Romanian government could promote a program called "Children love skiing" (inspired by the Austrian model), which will target the motivation of young people to practice winter sports, and the Ministry of Regional Development and Tourism will initiate a new promotional policy specific for these segments of tourists after developing an interactive data base that includes statistical information about the youth categories that practice tourism;

- Conducting market researches by specialized bodies for the Ministry of Regional Development and Tourism about the primary, secondary and opportunity markets of young tourists in order to gather information about: the market's size and potential (including prospects), the profile and features of the key market segments that should be aimed, the assessment of the possible future mix between tourist packages and tourists who travel on their own, the assessment of the efficiency of various marketing tools and techniques, promotion and public relations in transforming the potential of key market segments.

\section{Legal and institutional measures:}

> The necessity of the governmental intervention in the area of youth travel. Currently, there is a wide gap between the relatively large role played by youth travel on the global tourism market and, implicitly, in Romania and the governmental strategies and programs in this field. The experience of countries that have succeeded to develop the youth travel market proves that the intervention of the government is absolutely necessary in terms of developing a distinctive tourism policy for young people and in terms of supporting economic agents in this area, as well as the initiatives of specialized bodies. In the absence of actual actions, such as the lack of a coordinated policy and the acknowledgement of the essential connection between youth travel and the educational, cultural and youth policies, Romania can't capitalize on the opportunities to develop this market and the industry of youth travel. For example, the state can intervene by regulating the allotting of vacation vouchers for young people, taking a cue from France (the country that initiated the system of holiday checks, which has been functioning since 1982) or Hungary (the system of rest checks introduced in 1998), thus resolving the issue of creating opportunities for young people who can't afford to pay the full price of the tourism product, or by initiating social programs aimed at youth (such as: "Young people love the sea", "Children love nature");

$>$ Coordinating policies with direct or indirect impact on youth travel both at the level of Europe and at the level of regions, local authorities and the Romanian tourism industry. These branches must cooperate more closely and must use the European financial instruments available from 2007 until 2013 in order to develop European youth travel, placing emphasis on the competitiveness of destinations and of the tourism sector, on the development of tourism enterprises, services and units, on creating jobs, on professional mobility and training and on the economic diversification and the development of European regions, particularly less developed regions;

Improving the legal framework specific for youth travel regarding the classification of accommodation units in Romanian youth travel, regulating recreational activities in school camps and recreation centers, professional training of the employees, such as tourist animators, tour guides, child and youth protection and security. Among the concrete measures that should be taken are: simplifying the methodological rules and the minimum criteria regarding the classification of accommodation units in Romanian youth travel, establishing the obligation to provide young tourists with minimum services, such as "tourist information in several international auxiliary languages" for all the hostels, regardless of the comfort level, as well as developing a regulation of internal organization regarding elements such as the conduct of young people inside accommodation units, the access program into the unit, the accommodation of chaperones (teachers, guides, etc.), the set up of the areas where visitors are welcomed or the ban on smoking inside accommodation units. 
In addition to general rules applicable to the tourism activity in our country, in the future we should also approach aspects related strictly to youth travel, namely: the training of the specialized personnel working in leisure centers (school camps) and in youth hostels, such as animators, tourist guides, etc.; child and youth protection and security during their travel and stay, which also involves public authorities, vacation organizers and service providers, as well as tourists and the accompanying teachers; and developing regulations that encourage and promote youth travel. At the same time, it's necessary to align our regulations with the European regulations.

4. Other actions designed to contribute to the development of Romanian youth travel:

Supporting the associative environment in the area of youth travel according to the model of countries with tradition (for example, France) in terms of creating several youth and student organizations that will promote this form of tourism and in terms of establishing publicprivate partnerships, as well as strengthening the institutional capacity of these organizations;

$>$ Increasing the number of investments in the infrastructure specific for youth travel by involving to a greater extent the small and medium-sized enterprises in this type of business and finding solutions for their funding by the Romanian government;

$>$ Developing human resources in youth travel. Priority should be given to the continuous training of the personnel working in accommodation units for young people, placing an emphasis on acquiring practical knowledge. Through various training programs, young people can pursue a career in hospitality and tourism (tourist animators in vacation centers, tourist guides, etc.). These training courses and the adoption of good practices, promoted also in the European Union, should be organized in all the eight regions of development of Romania, which are becoming increasingly more significant for regional development;

> Developing studies and statistics regarding youth travel by the Ministry of Regional Development and Tourism and by other specialized bodies. The lack of detailed and accurate statistical information represents and major impediment for the detailed tourism planning in our country. Gathering and analyzing data allows to shape the trends that are manifesting in youth travel at national level, and at regional and local level is very important to conduct different studies and researches regarding tourist arrivals, number of night stays, occupancy level, tourist expenditure, modes of transport, as well as the degree of meeting the needs of tourists;

$>$ Adopting and implementing a modern management in order to efficiently manage school camps and youth recreation centers, which are under the administration of the Ministry of Research, Education, Youth and Sports and which play an important role in the educational process. To achieve this objective, we must consider the policy of the Romanian government in the area of youth recreation programmes and how to best organize and finance youth camps;

$>$ Helping companies and associations that manage the accommodation units for young people to become affiliated to national and international organizations (for example, Youth Hostel Association Romania, EURO<26 Romania Association, E.U.F.E.D., B.I.T.S. etc.);

$>$ Extending the organization of youth training programmes in jobs and professions in tourism, such as tourist animators in recreation centers and at the destinations preferred by Romanian and foreign youth;

$>$ The more strict application of the rules of occupational standards regarding the training of employees who work in tourism in general and in youth travel in particular;

$>$ Expanding participation projects for youth associations, clubs, foundations or any other form of non-governmental organization to the co-management of tourism resources in terms of the sustainable development of tourism by: attracting and supporting youth and their organization in campaigns for the identification of potentially perishable tourist areas; supporting the local initiatives of NGOs in marking, setting up and ensuring security in protected natural areas at national, regional and local level; supporting youth associations that set up certain areas (for example, marking alpine routes) to benefit of minimum rates in accommodation units located in that 
area.

All these actions, as well as the organisations responsible for their implementation are synthesized as follows (see table no.1):

Table no.1

Proposals for implementing the strategic goals of youth tourism in Romania

\begin{tabular}{|c|c|c|}
\hline Objective & Measures/Actions & Responsible organizations \\
\hline $\begin{array}{l}\text { Developing and } \\
\text { diversifying the tourism } \\
\text { supply }\end{array}$ & $\begin{array}{l}\text { - } \quad \text { Developing infrastructure; } \\
\text { - } \quad \text { Developing and diversifying tourism } \\
\text { products; } \\
\text { - } \quad \text { Training intermediaries in youth travel; } \\
\text { - } \quad \text { providing discounts and facilities; } \\
\text { - } \text { improving the quality of tourism services }\end{array}$ & $\begin{array}{l}\text { Economic agents that activate in } \\
\text { youth travel }\end{array}$ \\
\hline $\begin{array}{l}\text { Improving tourist } \\
\text { information services }\end{array}$ & $\begin{array}{l}\text { - Creating a network of tourist information } \\
\text { centers; } \\
\text { - Writing informative materials; } \\
\text { - } \quad \text { Designing specialized websites; }\end{array}$ & $\begin{array}{l}\text { Economic agents that activate in } \\
\text { youth travel }\end{array}$ \\
\hline $\begin{array}{l}\text { Tourism promotion and } \\
\text { marketing }\end{array}$ & $\begin{array}{l}\text { - Attracting new segments of clients; } \\
\text { - Promoting Romania as a tourist destination } \\
\text { by designing specialized websites and } \\
\text { participating at tourism fairs; } \\
\text { - Developing and implementing a youth } \\
\text { marketing strategy }\end{array}$ & $\begin{array}{l}>\text { Governmental bodies and } \\
\text { agencies } \\
>\text { Ministry of Regional } \\
\text { Development and Tourism } \\
>\text { Economic agents that activate in } \\
\text { youth travel } \\
>\text { Youth associations and } \\
\text { organizations }\end{array}$ \\
\hline $\begin{array}{l}\text { Governmental intervention } \\
\text { in youth travel }\end{array}$ & $\begin{array}{l}\text { - Developing and implementing } \\
\text { governmental strategies and programmes in } \\
\text { this field; } \\
\text { - Supporting the initiatives in youth travel; } \\
\text { - Initiating social programs for young people }\end{array}$ & $\begin{array}{l}>\text { Ministry of Regional } \\
\text { Development and Tourism } \\
>\text { County Directions for Sports } \\
\text { and Youth } \\
>\text { Local authorities }\end{array}$ \\
\hline $\begin{array}{l}\text { Aligning Romanian } \\
\text { economic and social } \\
\text { policies with European } \\
\text { policies }\end{array}$ & $\begin{array}{l}\text { - signing partnerships between Romania and } \\
\text { various EU countries or signing partnerships } \\
\text { at regional and local level in order to develop } \\
\text { policies that include youth travel }\end{array}$ & $\begin{array}{l}\text { Romanian government and the } \\
\text { governments of other countries } \\
\\
\text { agencies }\end{array}$ \\
\hline $\begin{array}{l}\text { Supporting the economic } \\
\text { and associative } \\
\text { environment }\end{array}$ & $\begin{array}{l}\text { - Creating more companies, youth } \\
\text { organizations and associations; } \\
\text { - Encouraging and supporting them in the } \\
\text { implementation of tourism programs for youth }\end{array}$ & $\begin{array}{l}\text { Individuals and companies with } \\
\text { initiative } \\
>\text { Associations and organizations } \\
>\text { Ministry of Regional } \\
\text { Development and Tourism } \\
>\text { Other authorities }\end{array}$ \\
\hline $\begin{array}{l}\text { Adopting and } \\
\text { implementing modern } \\
\text { management }\end{array}$ & $\begin{array}{l}\text { - The efficient management of school camps } \\
\text { and youth recreation centers, which are under } \\
\text { the administration of the Ministry of } \\
\text { Research, Education, Youth and Sports }\end{array}$ & $\begin{array}{l}\text { Ministry of Regional } \\
\text { Development and Tourism } \\
>\text { Associations of employees } \\
\text { working in tourism }\end{array}$ \\
\hline $\begin{array}{l}\text { Developing human } \\
\text { resources in the area of } \\
\text { youth travel }\end{array}$ & $\begin{array}{l}\text { - The continuous training of the personnel } \\
\text { working in specific units; } \\
\text { - Organizing programs for the training of } \\
\text { young people in tourism trades and } \\
\text { professions }\end{array}$ & $\begin{array}{l}>\text { Ministry of Regional } \\
\text { Development and Tourism } \\
>\text { Various trainers }\end{array}$ \\
\hline
\end{tabular}

Source: prepared by author

These objectives could be achieved by implementing the mentioned measures through the combined efforts of the specialized bodies in partnership with the agents that are directly involved in tourism. The need to develop youth travel in Romania answers to a triple perspective: the perspective of operators to the extent to which developing and diversifying the supply can improve the competitiveness of the sector; the perspective of young tourists because it provides answers regarding the satisfaction of their cultural, educational, relaxation, etc. needs; the perspective of public authorities, because the implementation of specific policies contribute to the overall socio- 
economic development.

Given that the tourism supply for youth travel in our country is quite varied, boasting a network of accommodation units that has a $4 \%$ share of total units, as well as specific products and programmes (camps, cultural events, music and sports events, cultural exchanges, mobility programmes, etc) and that the tourism demand has a similar share (3\% of the total number of tourists is represented by young people), we can assess that the specific tourism market has real prospects of development; however, Romania is still far from being an important tourist destination on the map of youth travel.

Capitalizing on current and future opportunities, the Romanian tourism industry must act fast in order to acknowledge young travellers as being a distinct and important market segment that has a significant potential for long-term development, and the general conclusion that emerges is that youth travel has big chances to develop in Romania, but their materialization requires to capitalize on the previous experience and to create a stimulating framework - legal, organisational, financial, marketing, etc.

\section{Conclusions}

Even if the main indicators of the national youth travel market reveal that it has an increasingly more important role in the overall tourism activity, we can say that, as in happens in other countries, youth travel isn't receiving the deserved attention in Romania, there is no development policy in this area and the issue of youth has to become an integral part of the national development strategy for tourism.

In the country, the proposals made, subsumed under the general developments and aggregates on three major directions: legislative and institutional framework, supply and marketing activities are established as strategic policy objectives in the field and accompanied by action plans /actions and responsibilities. Although many of these proposals remain stationed in the area of general or not accompanied by cost estimates quantitative effects, their implementation in practice will lead certainly a development of youth tourism in our country and perhaps what is most important, a reconsideration of its role and contributions of economic and social.

To summarize, one can say that Romania has a favourable framework for the development of youth travel, which is materialized in the economic evolution, the legal and institutional framework, the variety of the tourist programmes and facilities, as well as the actions conducted in partnership with bodies from EU countries, but without a clear and viable strategy accompanied by concrete measures and actions, this form of tourism can not be positioned among the most important forms of tourism. This is the only manner in which our country can become an important tourist destination that attracts young people from all over the world.

Romanian youth travel is facing important opportunities and challenges that require more cooperation and professionalism if this sector of tourism wants to have favourable prospects for development.

\section{References}

1. Istrate I., Glăvan V., 1994. Turismul cultural în România - liant al spiritualității româneşti de pretutindeni, Tribuna Economică nr. 5

2. Gonzalez Ortega M.L., 2002. Managing Heritage Tourism: challenges for the management of urban heritage cities and attractions, Université de la Savoie, Chambéry

3. Jones D., 2007. Social Tourism in the E.U. - Student \& Youth Travel, European Commission Seminar, Brussels 
4. Pătruț (Moisă) C.O., 2011. Realities and perspectives regarding youth travel in Romania and in the european context, Doctoral Thesis, Bucharest Academy of Economic Studies, Bucharest

5. Richards G., Wilson J., 2003. Today's Youth Travellers: Tomorrow's Global Nomads. New Horizons in Independent Youth and Student Travel, International Student Travel Confederation (ISTC), Amsterdam

6. Richards G., Wilson J., 2008. The changing context of cultural tourism, ATLAS (Association for Tourism and Leisure Education), Arnhem

7. Agenția Națională pentru Sprijinirea Iniţiativei Tinerilor (A.N.S.I.T.), 2007. Starea tineretului şi aşteptările sale - Diagnoză 2007, available online at http://ansitbrasov.ablog.ro/2008-03-13/starea-tineretului-si-asteptarile-sale.html

8. Agenția Națională pentru Sprijinirea Inițiativei Tinerilor (A.N.S.I.T.), 2008. Starea socială şi aşteptările tinerilor din România. Barometrul de Opinie Publică - Tineret 2008, available online at http://bratin.ablog.ro/2008-10-01/barometrul-de-opinie-public-tineret-2008.html

9. Autoritatea Națională pentru Tineret, 2006. Strategia D.P.R.D.T. pentru 2007.

10. BITS, 2001. Les concepts de tourisme pour tous et de tourisme social dans l'Union Européene, Seminaire from Bruges, june.

11. Government Ordinance no. 81/05.02.2010 regarding organisation of Ministry of Education, Research, Youth and Sports, published in Oficial Gazette no. 86 from 09.02.2010.

12. Parliament European - Rapporteur Costa P., Report on a renewed EU Tourism Policy: Towards a stronger partnership for European Tourism, Parliament European - Committee on Transport and Tourism, Bruxelles, 17 october 2007, available online on www.skytrip.ro (12.05.2011).

13. Regroupement Tourisme Jeunesse, 2001. Étude de produits et de marchés - Le tourisme jeunesse au Québec, Montréal, available online at http://www.tourisme.gouv. qc.ca/publications/media/document/etudes-statistiques/tour_jeunesse.pdf

14. Travel \& Tourism Analyst, 2004. Report Youth Travel Market- Europe, October, available online at http://www.marketresearch.com/Mintel-International-Group-Ltd-v614/YouthTravel-Europe-1063682/

15. Travel \& Tourism Analyst, 2009. Report Youth Travel Accommodation-International, June, available online at http://www.wysetc.org/resource/resmgr/research_reports/ staywysebenchmarkstudy-a4-e.pdf

16. U.N.W.T.O., 2009. UNWTO World Tourism Barometer, Volume 7, No. 1, January Madrid, available online at http://www.toinitiative.org/fileadmin/docs/ActivityReports/ press_rel/UNWTO_Barom09_1_en_excerpt.pdf

17. World Tourism Organization and Romanian Government, 2007. National Tourism Development Master Plan 2007- 2026, available online at http://www.infotravelromania.ro/master_plan_turism/master_plan.pdf

18. World Tourism Organization, 1991. International Conference on Youth Tourism-Final Report, New Delhi, India, 18-21 November.

19. World Travel and Tourism Council (WTTC), 2009. Travel \& Tourism Economic Impact, WTTC, Oxford, available online at www.oxfordeconomics.com

20. World Tourism Organization, World Youth Student and Educational Travel Confederation, 2008. Youth Travel Matters - Understanding the Global Phenomenon of Youth Travel, World Tourism Organization, Madrid.

21. www.euro26.ro - site of Romanian Euro<26 Association

22. www.studenttravel.ro - site of Youth Travel Agency „Student Travel Romania”

23. www.isic.ro - site of International Student Identity Card Association

24. www.hihostels-romania.ro - site of Youth Hostel Romania Association 